\title{
Debaryomyces or Debaryozyma?
}

\author{
J. LODDER ${ }^{1}$ AND N. J. W. KREGER-vAN RIJ ${ }^{2}$ \\ Jerfaasplantsoen 9, Bennekom, ${ }^{1}$ and Laboratory for Medical Microbiology, Oostersingel 59, Groningen, ${ }^{2}$
} The Netherlands

The name Debaryomyces Lodder et Kreger-van Rij has been proposed for conservation and, pending a recommendation by the General Committee, is still applicable.

Lodder and Kreger-van Rij (2) separated the Debaryomyces species with a strong fermentative ability from those lacking this ability. The former, including the type species Debaryomyces globosus Klöcker, could be classified in the genus Saccharomyces; the latter comprised several species which had been in Debaryomyces since 1913. Since the type species had been removed, the name Debaryomyces could not be maintained for this group, unless the name was conserved. Therefore, the authors provisionally indicated the genus as Debaryomyces Lodder et Kreger-van Rij nom. conserv., with the intention of making a formal proposal for conservation to the General Committee and awaiting a decision by the International Botanical Congress. This proposal was not made until 1978 (2a). Meanwhile, examinations with newer methods $(1,3$, 5) have supported the splitting of the genus Debaryomyces Klöcker. Van der Walt and Johannsen (4), apparently unaware of the previous publication of the proposal for conservation of the name Debaryomyces Lodder et Kreger-van Rij, have now described a new name, Debaryozyma, for the species in this genus.

Recommendation $15 \mathrm{~A}$ of the International Code of Botanical Nomenclature (3a) states that botanists should follow existing nomenclature as far as possible pending a recommendation for the proposal by the General Committee. In this case it means that the name Debaryomyces is still applicable. The composition of the General Committee is mentioned in the Code (page 69). To avoid confusion and accumulation of syn- onyms, we consider it expedient to bring again our proposal to the attention of yeast taxonomists.

\section{REPRINT REQUESTS}

Address reprint requests to: Dr. N. J. W. Kreger-van Rij, Laboratory for Medical Microbiology, R.U., Oostersingel 59, Groningen, The Netherlands.

\section{LITERATURE CITED}

1. Kreger-van Rij, N. J. W., and M. Veenhuis. 1976 Ultrastructure of the ascospores of some species of the Torulaspora group. Antonie van Leeuwenhoek J. Microbiol. Serol. 42:445-455.

2. Lodder, J., and N. J. W. Kreger-van Rij. 1952. The yeasts, a taxonomic study. North-Holland Publishing Co., Amsterdam.

2a. Lodder, J., and N. J. W. Kreger-van Rij. 1978. Proposal (446) for the conservation of the generic name Debaryomyces Lodder et Kreger-van $\mathrm{Rij}$ against Klöker. Taxon 27:306-307.

3. Price, C. W., G. B. Fuson, and H. J. Phaff. 1978. Genome comparison in yeast systematics: delimitation of species within the genera Schwanniomyces, Saccha. romyces, Debaryomyces and Pichia. Microbiol. Rev. 42:161-193.

3a. Stafleu, F. A., C. E. B. Bonner, R. McVaugh, R. D. Neikle, R. C. Rollins, R. Ross, J. M. Schopf, G. M. Schwalze, R. De Vilmorin, and N. E. G Voss (ed.). 1972. The International Code of Botanical Nomenclature. Adapted by the 11th International Botanical Congress, Seattle 1969. A. Oosthoek Uitgevers Mij. N. V., Utrecht.

4. van der Walt, J. P. and E. Johannsen. 1978. The genus Debaryozyma van der Walt \& Johannsen, nom. nov. Persoonia 10:146-148.

5. Yamada, Y., M. Nojiri, M. Matsuyama, and K. Kondo. 1976. Coenzyme $Q$ system in the classification of the ascosporogenous yeast genera Debaryomyces, Saccha romyces, Kluyveromyces and Endomycopsis. J. Gen. Appl. Microbiol. 22:325-337. 